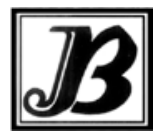

J. Bio-Sci. 28: 51-57, 2020

ISSN 1023-8654 http://www.banglajol.info/index.php/JBS/index DOI: https://doi.org/10.3329/jbs.v28i0.44710

\title{
ASSESSMENT OF PRESENT ENVIRONMENTAL STATUS OF THE RATARGUL SWAMP FOREST SYLHET
}

\author{
T Siddika ${ }^{1 *}$, MAK Azad², MH Sujan ${ }^{3}$ and MM Hasan ${ }^{3}$ \\ ${ }^{1}$ The Sylhet Khajanchibari International School and College, Sylhet, Bangladesh \\ ${ }^{2}$ Department of Botany, Directorate of Secondary and Higher Secondary, MoE, Bangladesh \\ ${ }^{3}$ Department of Geography and Environment, School of Physical Sciences, Shahjalal University of Science \\ and Technology, Sylhet 3114, Bangladesh
}

\begin{abstract}
This study aims to find out the present environmental status and issues that have emerged in the recent time due to change in human activities, resource extraction and human dependency on the forest. This study is based on both qualitative and quantitative approach with Participatory Rural Appraisal (PRA) tools and random sampling of 260 respondents, six focus group discussions (FGDs), six key informants interviews (KIIs). The result suggests that about $90 \%$ of poor and middle-classhouseholds are depended on the income from tourism, agriculture or boat riding activities. Both the local people and tourists' activities are responsible for decreasing environmental condition by plastic pollution, land cover and land use change, water follows control, road and building construction and violence of rules and regulation. The south and east boundaries, and the center of the forest are mainly facing land use and land cover changes between the years of 2005 to 2018. For sustainable management, local communities should be aware of the importance of swamp forest and have to find out alternative income sources to reduce pressure on swamp forest in terms of resources extraction and forest degradation.
\end{abstract}

Key words: Degradation, Ecotourism, Environmental assessment, LULC, Swamp forest

\section{Introduction}

A forest is considered to be a swamp forest which is inurned or full of fresh water either a permanent, irregular or seasonal condition. These kinds of forest wetland are found on the lower parts of a river or freshwater lakes in many different regions having a wide range of climate types. In the world, there is only 22 freshwater swamp forest that is considered as a 'biological supermarket' for its rich biodiversity (Nabahungu and Visser 2011). In the wetlands area of Bangladesh, there are 5,000 species of flowering plants; 1,500 species of vertebrates (750 species of birds; 500 species of coastal, estuarine, fresh-water fishes inhabit) animals. However, 400 species of vertebrates and 300 species of plants depend upon the wetlands for their total life cycle or part of life. Almost 260 species of fresh-water fishes exist in the wetlands (Bhuiyan 2013). The Ratargul forest contains around 73 species of trees, 26 species ofmammals, 20 species of reptiles, 175 species of birds and 9 species of amphibians (Jahan and Akhter 2018) and yet its area is only 114.11 ha. Because of this rich biological diversity, the Ratargul forest has been declaredas 'Special Biodiversity Protected Area' by the Ministry of Environment and forests of Bangladesh on May 31, 2015, through a Gazette notification. But the recent studies found that this unique forest is undergoing few anthropogenic and natural threats that impacting on the biodiversity and the ecosystem of the forest. A recent study by Islam et

*Author for correspondence: tahiaa82@gmail.com 
al. (2016) found that about 94 species of fish inhabiting the Ratargul Swamp Forest, 28 species are threatened, of which 14 are vulnerable, 10 are endangered and 4 are critically endangered. In 2004, IUCN also reported that Surrounding people totally or partially depend on this wetland in different ways. A handsome amount of rice, fodder and fuel comes from this wetland area. Many people collect patipata (Schumannianthus dichotoma) from this forest which is used for making handicrafts, thatching materials etc. Fishing is an important source for livelihood that is carried out during rainy season. Some people catch fish occasionally to meet only their demand and most of people catch fish professionally. These fishes are sold in the market and earn cash money. Therefore, in this paper, it was explored the present condition of the Ratargul Swamp Forest in terms of environmental condition, human dependency and effect of ecotourism on the biodiversity and the ecosystem of the forest along with the life and livelihood of the local people of who are directly or indirectly depended on the forest.

\section{Materials and Methods}

\section{Study area}

Ratargul Swamp Forest is chunk under the Sylhet Forest Division. It is located at about $45 \mathrm{~km}$ on the NorthWest of Sylhet town on the bank of Goyain. The administrative location of the site is under UpazilaGoainghat and district Sylhet. The administrative beat office is situated at latitude $25^{\circ} 00.025^{\prime} \mathrm{N}$ latitude and $91^{\circ} 58.18^{\prime} \mathrm{E}$ longitude (IUCN 2004).

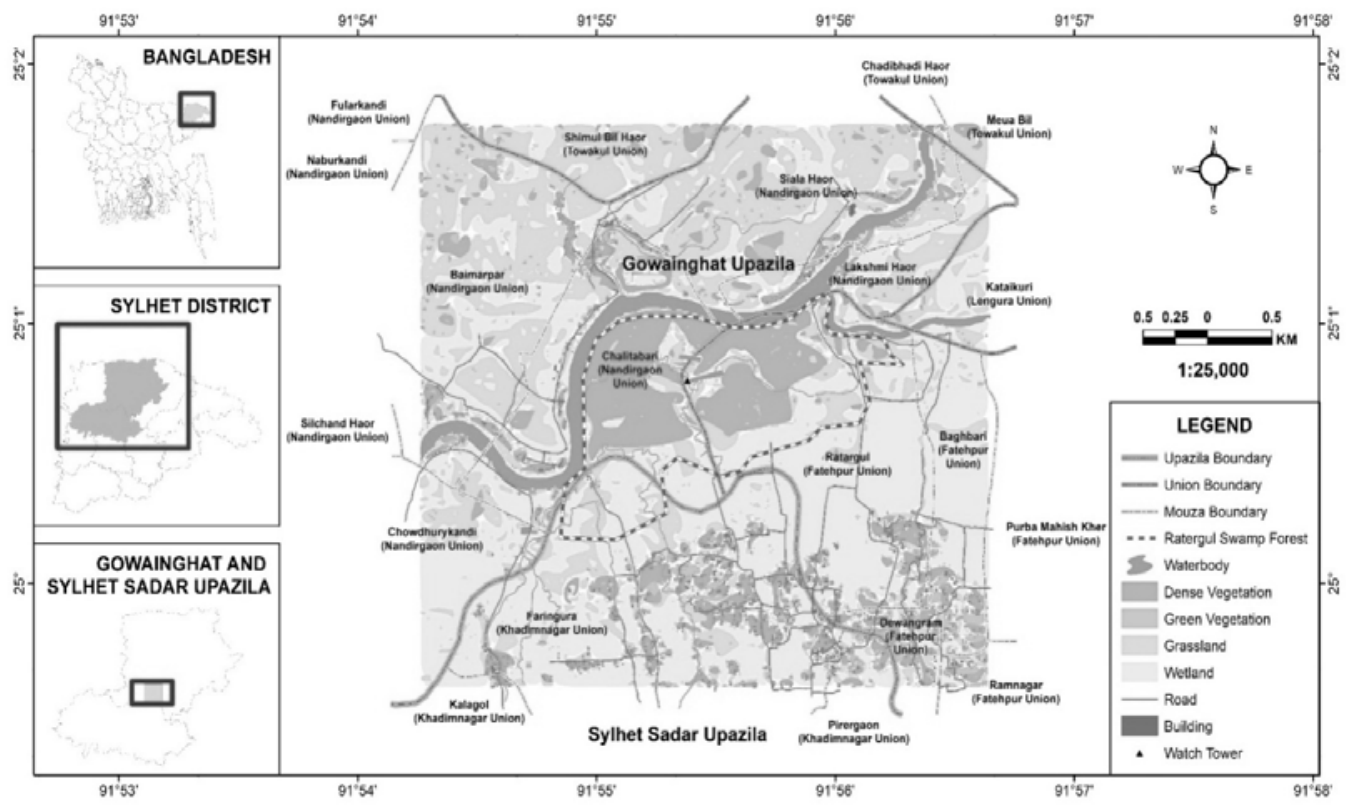

Fig. 1. Location of the study area of Ratargul Swamp forest. 


\section{Sample size and distribution}

A number of Participatory Rural Appraisal (PRA) tools were used to collect environmental related data from the local people based on respondent's perceptions. The PRA is a key approach where local people are able to share, enhance and analyze their information concerning to lifestyle, condition and to plan and act (Chambers 1994) using the techniques of household survey, key informant interviews (KIIs), focus group discussion (FGDs) with semi-structured questionnaires. The recognized sample size determination formula (Salganik 2006) [on the basis of 50\% indicator percentage, 95\% confidence interval, and 0.07 precision and highest response distribution with an assumed design effect 1.33] with cluster sampling design yields that at least 260 respondents were required for the study. For the study, 6 FGDs and 6 KIIs had been carried out from the three villages viz. Aolarkut, Ratargul and Chiringi.

\section{Images analysis}

Remote sensing is a process that helps to detect and monitor the physical characteristics of an area by measuring its reflected and emitted radiation at a distance from the targeted area (USGS 2019). In this study, only the spatial changes of land use is measured and visualized to aid the information as possible from the images. As Ratargul Swamp forest is coverered only of area and having short of fund to carry out a highresolution image of different years, a Google Earth Pro images of four different years $(2005,2008,2015$ and 2018) have been taken to visualize the changes of the forest by years (Hu et al. 2013, Malarvizhi et al. 2015). For analysis and graphical representation of results, IMM SPSS Statistics 25.0, Microsoft Excel, ArcGIS 10.4.1 softwares had been used in this study.

\section{Results and Discussion}

\section{Occupational dependency of local people on the forest}

A new door of income has been unlocked for the local people due to ecotourism in Ratargul swamp forest. The study had found that dependency had been increased on the existing natural resources of the forest through changing the occupation type of local people. In the study, household level economic status had been measured based on the total household income and classed into 5 category viz. very poor (0-100 USD), poor (101-150 USD), middle class (151-200 USD), rich (201-250 USD) and very rich (250+ USD). The study result revealed that about two-fifths of the respondents were belongs to middle class family (Fig. 2). At the same time, quarter of them were belongs to poor family (25.24\%) and about one-fifths were very poor family $(18.5 \%)$. Rest of the respondents of the there villages were either rich or very rich considering their families monthly income.

Occupational dependency based on economic status of local people on the Ratargul Swamp Forest were shown in the Fig. 2. Agriculture, tourism, boatman, collection of fuel, fodder, shopkeeping and hunting are the major economic activities by the local people of the three villages: Aolarkut, Ratargul and Chiringi. The cross tabulation analysis (between family income and occupation type) reveals that majority of the local people of this forest area are engaged in tourism (25.8\%) and agricultural (23.37\%) occupation (Fig. 2). About onefifths (18.4\%) of them are depends on seasonal occupation named boat riding. Among the groups of occupations, most of the middle class family whose monthly income ranged between 1500-2000 USD are engaged in tourism and agriculture. From the study, it was also found that the poor and very poor group of families was mainly involved in tourism, agriculture, fishing and boat riding (Fig. 2). 


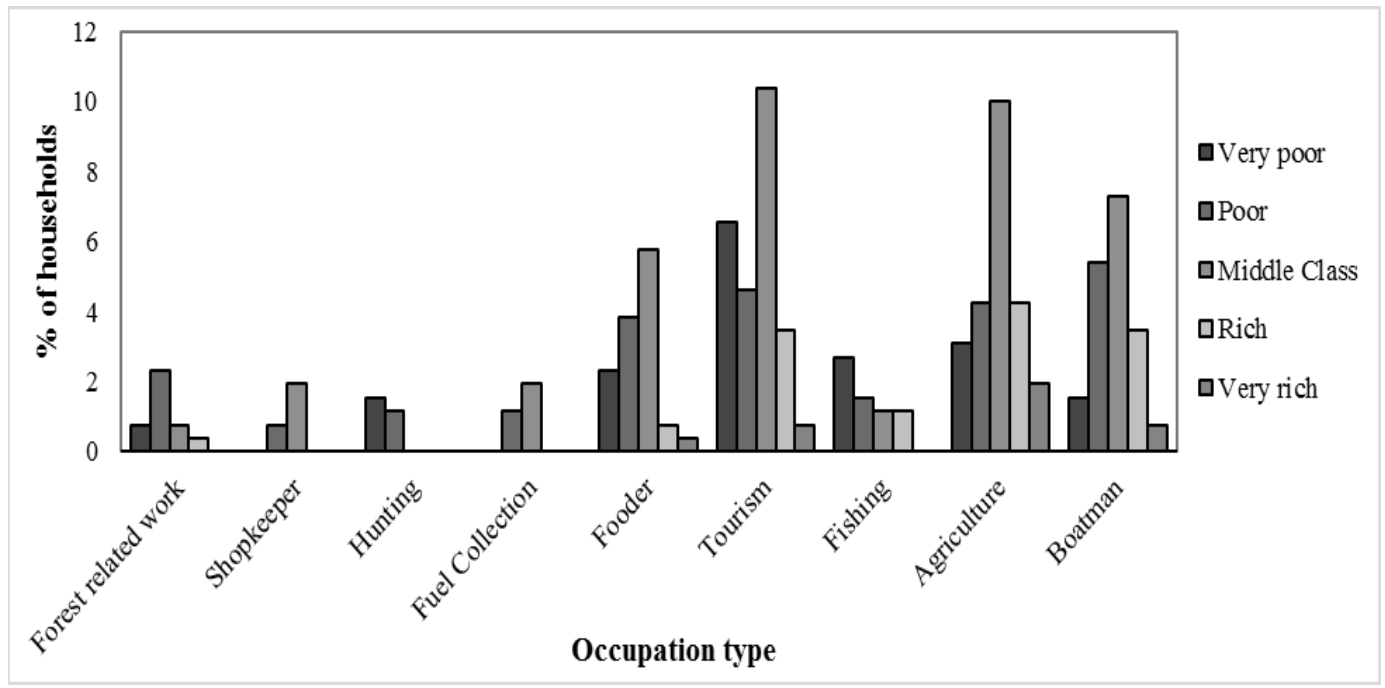

Fig. 2. Occupational dependency based on economic status of local people on the Ratargul Swamp forest.

Through FGDs survey, it was found that dependencies on the forest for fuel wood and fishing as an occupation, has been decreased dramatically in recent years. The dependencies (occupational change) have been changed because of law enforcement by the Ministry of Environment and Forests of Bangladesh on May 31, 2015 by this year, Ratargul swamp forest has declared as an eco-tourist spot which made a direct influence on the local people' dependency on the forest by shifting their occupation to tourism. There are about 150 boats at Ratargul village boat ghat which is the only media for transportation in the forest both in the dry and wet season.

From the key informants' interviews (KIls and FGDs) it is found that this shifting in dependencies of local people on the forest is impacting on the forest directly by changing the natural set up of the forest, impacting on the ecosystem and biodiversity. As human interruption in the day time has increased a hundred times (both local and outsiders) within only six to ten years for the introduction of ecotourism.

\section{Changes of forest area}

The images of four different years $(2005,2008,2015$ and 2018) of the forest suggest that the land use and land cover (LULC) has been changed in various aspects (Fig. 3). The main changes have occurred in the east and south edges of the forest which has no natural boundary like the other two sides with Shari-Goyain River. Mainly the anthropogenic activities are high in this area and land use has been changed from forest area to agricultural area. Another major alteration of the forest is the change of vegetation density both in the inside and the outer part of the forest. From the images, it is clear that there is a significant change in the middle core area of the forest. New canals were excavated through the forest and few areas had been altered to deep water body from shallow water body. 


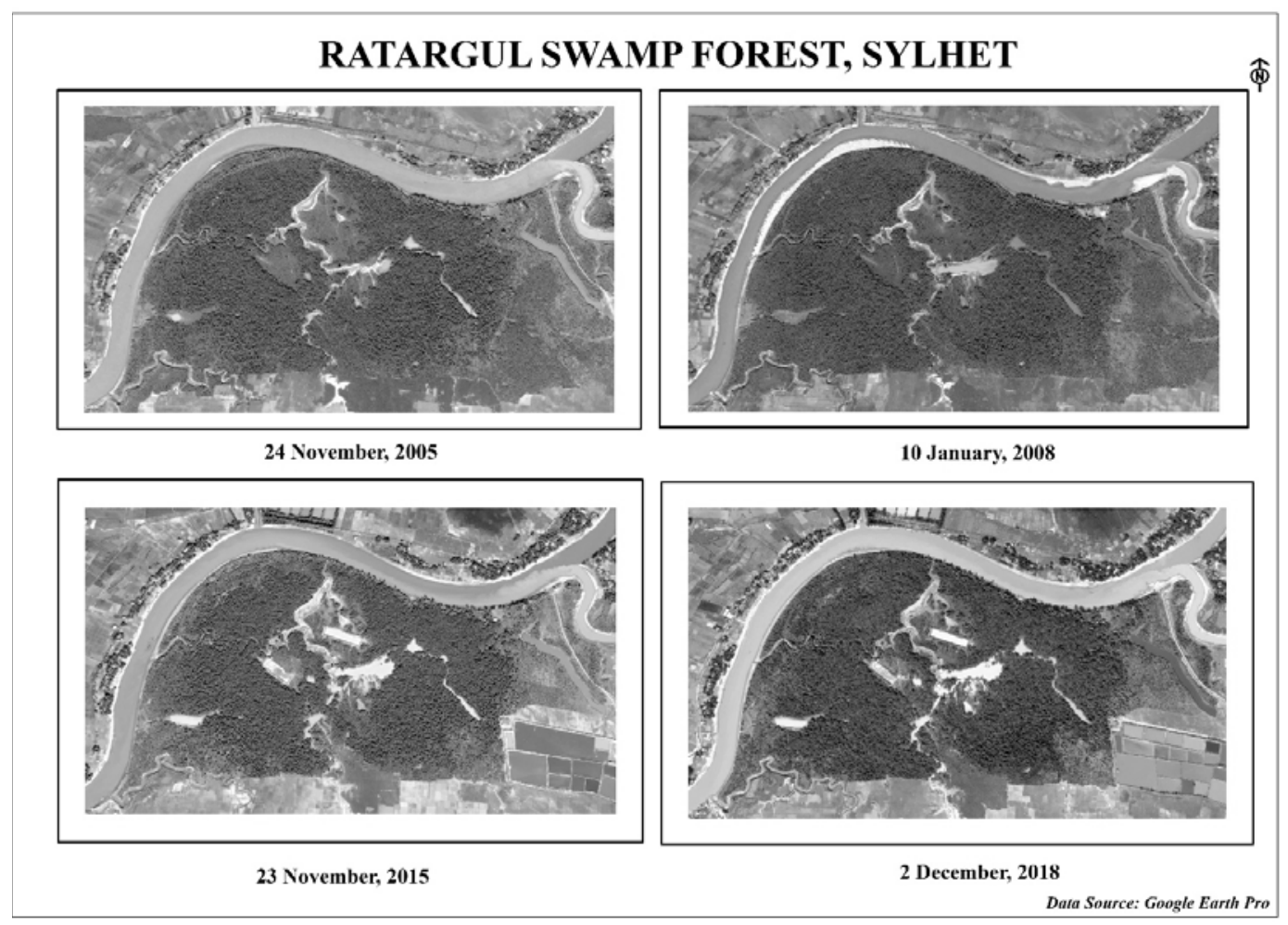

Fig. 3. Change in Land use and land cover in Ratargul Swamp forest from 2005 to 2018.

The natural waterflow of Khoiyar canal (locally known as Khoiyar khal) had been transformed because of the human intervention through dam construction to facilitate the tourism round the year. From the focus group discussions (FGDs), it was found that land use changes had been primarily started to facilitate the fishing activity. Moreover, water follows in the dry season is controlled in the forest that has a direct effect on the plants, animals and the ecosystem (Fig. 3).

\section{Environmental issues of the forest}

Both the qualitative and quantitative approach has been followed to quantify and identify the major environmental issues related to Ratargul swamp forest. On the basis of observation and respondents survey, it was found that both the local people and the outsiders are creating a few major environmental concerns in recent times by changing the forest with their activities. The environmental issues are emerged in recent time mainly occurring due to introduction of ecotourism. The survey result found that more than one thousand number of tourists visit in this area. But the forest is too little to bear this number of tourists every day. The local people stated that the weekend days (Saturday and Friday), government holidays, any kind of religious festival, rainy season (from June to September) are the peak time when tourists visit the forest in maximum.

About nine-tenth respondents ( $91.53 \%$ out of 260 respondents) stated that tourist is mainly responsible for plastic pollution. One of the respondents added that if only 100 plastic packets are added in the forest then, it would be 36500 in a year and it will be 365000 after ten years. It indicates that if each of the plastic packets 
would be half square inch in the area then after 10 years one-fourth of the forest will be covered by plastic materials. Though, it is estimated that the reality is too much more severe. As there is no dumping zone, the collected plastic mixed with the water and soil with runoff water in the rainy season. During this season, the tourists are maximum in this eco-tourist spot. The main types of plastics found in the forest are different types of poly packet, chocolate, and chewing gum packs, plastic water bottles, polythene bags, soft drinks bottles.

The presence of overloaded tourists all year round causing serious impact on the biodiversity of the forest. The previous study suggests that this area contains a large number of faunal and floral biodiversity (IUCN 2004, Islam et al. 2016, Das et al. 2017). According to the local people, in the winter season, the number of migratory birds had decreased tremendously in the last five years (2014-2018). Most of the respondents (80.92\%) reported that during this period (last five years), ecotourism has developed in the forest area. The government authority (through KIIs) stated that once there were about 73 plant species, 20 species of reptiles, 26 species of mammals and 175 species of birds in the forest. Locals opined that most of the species have already disappeared or become extinct due to the food crisis and loss of their habitats. According to the respondents, one-fourth tourist is responsible for sound pollution, more than three-fifths by not maintain the tourist guidelines, three-fifth by disturbing the biodiversity, one-third by photography and so on.

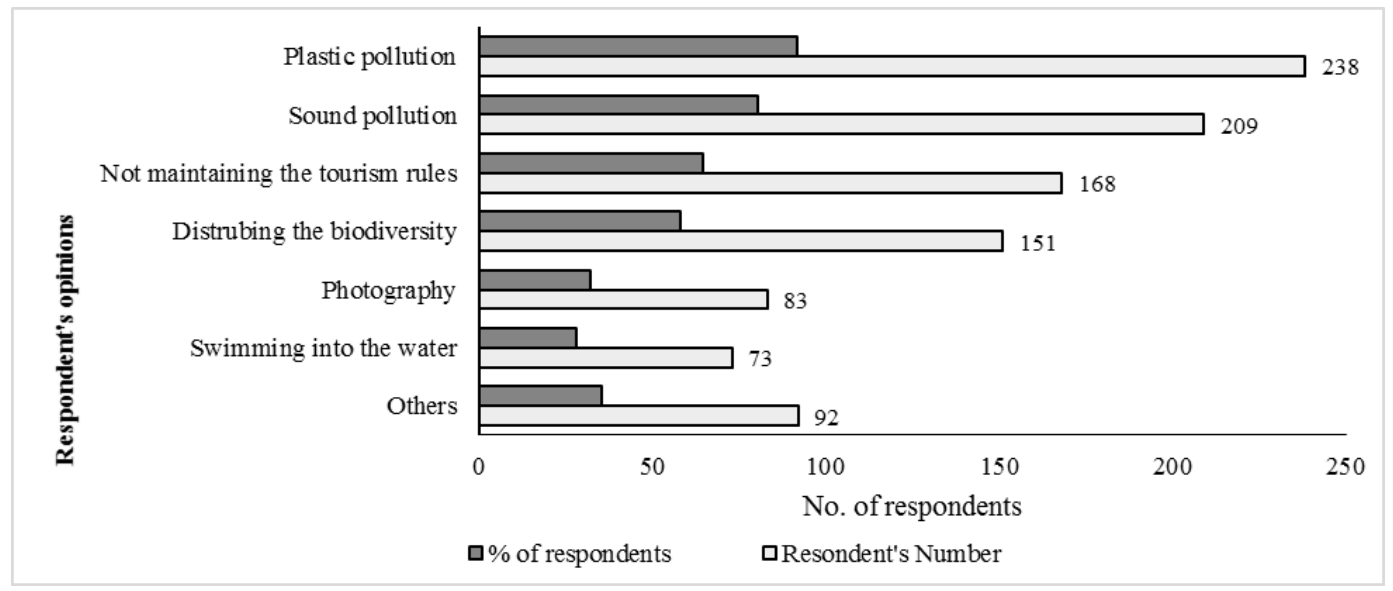

Fig. 4. Tourists activity in the forest that creating an environmental problem.

IUCN report in 2004 suggested that this swamp forest gets dried up in the late winter and pre-monsoon season. In this condition different medicinal plants grow up. But the observation survey and satellite image from the Google Earth Pro suggests that this area (mainly the Chengirkhal) controlled by artificial embankment and dam. The canal also had been dug around the middle part of the forest to facilitate the boats in the dry season. This activity has a direct impact on the total ecosystem. The key informants commented that it's an anti-ecotourism activity and not sustainable for the forest. It has a direct immediately and long-term impact on the forest ecosystem. 


\section{Conclusion}

The results of the study demonstrate that absence of distinct forest boundary, high dependency on forest, absence of operation of standing law and implication of policy, inadequacy of administrative people, no fixed tourist rules etc. are causing the major threat to the present environment of the Ratargul Swamp forest. Though, working together with local community, forest department, national and international NGO's, research organizations, and others volunteer organization (participatory forest management approach) could be effective techniques to overcome prevailing difficulties of Ratargul Swamp forest.

\section{References}

Bhuiyan MR (2013). Wetland Management of Bangladesh- A Sustainable Bio-diversified Approach. Nature Study Society of Bangladesh (NSSB). http://www.naturestudysociety.org/wetland-management-in-Bangladesh.

Chambers R (1994). The origins and practice of participatory rural appraisal. World Development, 22(7): 953-969.

Das KS, Roy CN and Hossain AM (2017). Diversity of indigenious fish species in ratargul freshwater swamp forest, Bangladesh. International Journal of Scientific Research in Environmental Sciences, 5(2): 28-35.

Hu Q, Wu W, Xia T, Yu Q, Yang P, Li Z and Song Q (2013). Exploring the use of google earth imagery and object-based methods in land use/cover mapping. Remote Sensing, 5: 6026-6042.

Islam MS, Islam AM, Sweety AN, Hossain M and Kabir HM (2016). Assessment of Aquatic Faunal Diversity in the Ratargul Swamp Forest at Sylhet in Bangladesh. Journal of Environmental Science and Natural Resources, 9(2): 51-64.

Islam MA, Islam MJ, Arefin S, Rashid A and Barman SK (2016). Factors affecting the fisheries biodiversity of Ratargul swamp forest of Sylhet district, Bangladesh. Journal of Environmental Science, Toxicology and Food Technology 10(1): 60-65.

IUCN (2004). Biodiversity of Ratargul Swamp Forest, Sylhet, Bangladesh. pp. 1-16.

Jahan MK and Akhter $\mathrm{H}$ (2018). Impact of ecotourism on the environment, society and culture of Ratargul swamp forest in Sylhet, Bangladesh. Asian Journal of Environment and Ecology, 8(1): 1-8.

Malarvizhi K, Kumar SV and Porchelvan P (2016). Use of high resolution google earth satellite imagery in landuse map preparation for urban related applications. Procedia Technology, 24: 1835-1842.

Nabahungu NL and Visser SM (2011). Contribution of wetland agriculture to farmers' livelihood in Rwanda, Journal of Ecological Economics, 71: 4-12.

Salganik JM (2006). Variance estimation, design effects, and sample size calculations for respondents-driven sampling, Journal of Urban Health, 83(1): 98-112.

USGS (2019). What is remote sensing and what is it used for?, United States of Geological Survey (USGS). https://www.usgs.gov/faqs/what-remote-sensing-and-what-it-used?

(Manuscript received on July 28, 2019 and revised on September 29, 2019) 
